\title{
Indirect Organogenesis for Regeneration in Brinjal (Solanum melongena L.) Var. KKM 1
}

\author{
A. Nivetha ${ }^{1}$, S. Merina PremKumari ${ }^{2 *}$, R. Kannan ${ }^{1}$, R. Arulmozhiyan ${ }^{3}$, \\ N. Rajinimala ${ }^{1}$ and M. Arumugam Pillai ${ }^{2}$
}

${ }^{1}$ Department of Plant Pathology, Agricultural College and Research Institute, Killikulam, Vallanadu-628252, Tamil Nadu, India

${ }^{2}$ Biotechnology Division, Department of Plant Breeding and Genetics, Agricultural College and Research Institute, Killikulam, Vallanad-628252, Tamil Nadu, India

${ }^{3}$ Department of Horticulture, Agricultural College and Research Institute, Killikulam, Vallanadu-628252, Tamil Nadu, India

*Corresponding author

\section{A B S T R A C T}

\section{Keywords}

Brinjal variety

KKM1 seeds,

Explants,

Sterilization, Callus

induction,

Regeneration

Article Info

Accepted:

20 June 2020

Available Online:

10 July 2020
Brinjal is an important nutritional vegetable crop of tropical and subtropical regions. It is highly responsive to various tissue culture techniques. The aim of this study was to develop an efficient protocol to standardize the concentration of sterilants for seed and explants sterilization for in vitro germination and regeneration respectively. The explants used are cotyledonary leaf, stem and hypocotyl of in vitro grown brinjal var.KKM1. For sterilization of seeds and explants, 5\% sodium hypochlorite treatment for 3 minutes is the most effective sterilant concentration against the microbiological contamination. In subsequence, the regeneration protocol was optimised for the brinjal var.KKM1. From the in vitro grown seedlings, different explants such as hypocotyl, cotyledenary leaf and stem were taken for callus induction. Highest number of callus was obtained in MS medium containing $2 \mathrm{mgl}^{-1} \mathrm{NAA}$ and $0.5 \mathrm{mgl}^{-1} \mathrm{BAP}$. Among the explants used, cotyledonary leaf and stem were highly responsive to callus induction. Further the callus was proliferated in the same media and was used for regeneration by using different plant growth hormones. Regeneration of shoots from callus was more efficient in MS media containing $2.0 \mathrm{mgl}^{-1}$ BAP, $1.0 \mathrm{mgl}^{-1} \mathrm{Kn}$ and $0.5 \mathrm{mgl}^{-1} \mathrm{NAA}$. The successful rooting was recorded on $1 / 2 \mathrm{MS}$ media supplemented with $0.5 \mathrm{mgl}^{-1}$ IBA. This in vitro regeneration process might be useful for producing disease free plants especially little leaf of brinjal, the most common infection in the brinjal var.KKM1.

\section{Introduction}

Brinjal is a widely adaptive and highly productive vegetable crop of tropical and subtropical regions. It is one of the important horticultural plants of the Solanaceae family. It has significant medicinal values (Khan, 1979). It has higher calorie, iron, phosphorous and riboflavin content. There are different varieties of brinjal according to colour and 
shape. One such variety KKM1 was developed through single plant selection from a local type collected from Kulathur area and released by Department of Horticulture, Agriculture College and Research Institute, Killikulam during the year 1995. The plants are compact bearing small-sized white coloured egg-shaped fruits in the cluster of 2 4 with green calyx. The potential yield is 36 tonnes/ha. This variety has got a local preference in Tirunelveli district of Tamilnadu.

Brinjal is affected by several biotic stresses and Phytoplasma associated disease is one of the most significant diseases that causes yield loss of up to 40 per cent (Mitra, 1993 and Rao et al., 2010). In India, little leaf disease of brinjal was first reported by Thomas and Krishnaswami (1939). The infected plants are characterised by small, soft, thin and malformed leaves showing yellow discolouration. The plants are generally stunted in growth with short internodes and auxiliary buds proliferation leading to phyllody symptoms (Rao et al., 2010). The brinjal variety, KKM1 is severely affected by the Phytoplasma little leaf disease and hence to address this problem, the present study was undertaken to produce disease free planting materials using tissue culture methods.

The common problem of contamination in tissue culture by various microorganisms such as bacteria and fungi affects the callus proliferation and regeneration. Hence effective explants sterilization method (Dodds and Roberts, 1985; Sen et al., 2013) is needed to produce disease free seedlings. Many sterilants cause toxicity to plant tissues and hence optimisation of the concentration of sterilization chemicals and duration of exposure of explants to sterilants are to be deduced for minimum explants injury to achieve better survival (CPRI 1992). The sterilization protocol of brinjal seeds for in vitro seed germination and the explants of in vitro seedlings viz, cotyledonary leaf, hypocotyl and stem for tissue culture is to be formulated for elimination of microbial contaminants by using different surface sterilizing agents such as sodium hypochlorite, mercuric chloride and ethanol.

The efficacy of in vitro organogenesis of brinjal highly depends on the type of explants used and complemented by a combination of plant growth regulators (Magioli and Mansur, 2005). Hence, the regeneration efficiency of brinjal var.KKM 1 is studied using different explants viz., cotyledonary leaf, hypocotyl and stem obtained from the in vitro germinated seedlings. With this prelude, the present study necessitates the development of an efficient sterilization protocol for the explants of brinjal var.KKM1. Also regeneration protocol optimisation from various explants of in vitro grown brinjal seedlings is a pre requisite for producing disease free plantlets for crop improvement.

\section{Materials and Methods}

\section{Sterilization of seeds and explants}

Seeds of brinjal variety KKM1 were obtained from the Department of Horticulture, Agriculture College and Research Institute, Killikulam. The seeds were washed in running tap water for 15 minutes. The nonviable floating seeds and debris were discarded. The washed seeds were subjected to sterilization using various sterilizing agents such as $5 \%$ sodium hypochlorite for $3 \mathrm{~min}$ and $5 \mathrm{~min}, 0.1 \%$ mercuric chloride for $2 \mathrm{~min}$ and $3 \mathrm{~min}$ and $70 \%$ ethanol for $10 \mathrm{sec}$ and $30 \mathrm{sec}$ under aseptic condition in laminar airflow chamber. Then the seeds were washed using sterile distilled water for 4 to 5 times and air dried by spreading on sterilized filter paper in a petridish. The sterilized seeds of ten to twelve numbers were inoculated in $100 \mathrm{ml}$ 
conical flasks containing $30 \mathrm{ml}$ agar solidified MS medium free of hormones and the seeds were allowed to germinate. The per cent germination of seeds was recorded after 7 days of inoculation. Similarly, the explants viz., cotyledonary leaf, hypocotyl and stem from in vitro germinated seedlings were sterilized following the above mentioned sterilization treatments for callus induction and contamination percentage was recorded in all explants.

\section{Callus induction}

The explants such as cotyledonary leaf, stem and hypocotyls were dissected out from 10 to 12 days old in vitro germinated seedlings and inoculated in MS medium supplemented with different combination of plant growth hormones viz., 2, 4-D at 2.0 and $3.0 \mathrm{mgl}^{-1}$, BAP at $0.5,1.0,1.5$ and $2.0 \mathrm{mgl}^{-1}$, IAA at 0.5 , 1.0, 1.5 and $2.0 \mathrm{mgl}^{-1}$ and NAA at $0.5,1.0,1.5$ and $2.0 \mathrm{mgl}^{-1}$ concentration. The inoculated explants were kept in dark condition with $26^{\circ} \mathrm{C}$ temperature for callus initiation. The calli formed were subcultured for every three weeks in the same media prepared freshly for callus proliferation.

\section{In vitro regeneration}

The friable and embryogenic calli is selected from the proliferated callus and was inoculated in MS medium supplemented with various combination of hormones viz., BAP at 2.0 and $3.0 \mathrm{mgl}^{-1}$, NAA at $0.5 \mathrm{mgl}^{-1}$ and kinetin at $1.0 \mathrm{mgl}^{-1}$ concentration for shoot initiation.

The inoculated callus cultures were kept in culture conditions of 2000 lux light intensity, $16 / 8 \mathrm{hrs}$ photoperiod and $26^{\circ} \mathrm{C}$ temperature. The regenerated shoots were transferred to rooting medium containing MS basal along with the hormone IBA at two different concentrations of 0.5 and $1.0 \mathrm{mgl}^{-1}$.

\section{Hardening}

The plantlets after sufficient development of root system, were taken carefully from the culture tubes and the agar was washed in running tap water. The plantlets were transferred to small plastic pots containing sterilized sand, soil and FYM in 1:2:1 ratio and kept inside the polyhouse for two to three weeks for acclimatization.

\section{Data recording and analysis}

The experiments were conducted in Completely Randomized Design. The analysis of variance for different characters was performed and means were compared by the Duncan's Multiple Range Test (DMRT).

\section{Results and Discussion}

\section{Sterilization of seeds and explants}

The chemical sterilants viz., sodium hypochlorite, mercuric chloride and ethanol were used at various concentrations and exposure time to determine the most efficient procedure for sterilization of seeds of brinjal var.KKM1 for in vitro germination and the explants viz., cotyledonary leaf, stem and hypocotyl from in vitro grown seedlings for callus formation (Table 1).

The germination of brinjal var.KKM1 seeds initiated within three to four days of incubation. The maximum germination percentage was recorded as $91.7 \%$ using $5 \%$ sodium hypochlorite for 3 minutes exposure and contamination percentage was 5.1 (Table 1; Fig 1c). The use of sodium hypochlorite for effective surface sterilization of explants from different plant sources has been widely reported (Durosomo et al., 2014; Anoop Badoni et al., 2010; Maina et al., 2010). The explants such as cotyledonary leaf, stem and hypocotyl for callus induction showed lesser 
contamination percentage of $3.86 \%, 5.2 \%$ and $6.0 \%$ respectively by using $5 \%$ sodium hypochlorite for $3 \mathrm{~min}$ exposure time compared to the exposure period of $5 \mathrm{~min}$ and other sterilizing agents (Fig 1d).

Treatment with $70 \%$ ethanol was not promising since the seed germination was $16.23 \%$ even though contamination was $15.33 \%$ and response of explants was not evident. The explants such as cotyledonary leaf, stem and hypocotyl used for callus formation also showed higher contamination percentage using 70\% ethanol (Table.1;Fig 1e,1f). Ethanol is phytotoxic and a strong sterilizing agent with good bacteriostatic activity. For these reasons, the explants should be exposed to a lower concentration of ethanol for a short period of time. But the use of reduced concentration of ethanol does not completely destroy bacteria and hence to improve effectiveness in sterilization procedure, ethanol is generally used prior to treatment with other sterilization compounds.

Mercuric chloride at $0.1 \%$ concentration for exposure time of 3 minutes recorded $73.33 \%$ germination and $7.10 \%$ contamination (Table.1; Fig 1a). The contamination percentage of cotyledonary leaf, stem and hypocotyls were recorded as $8.86 \%, 8.4 \%$ and $8.4 \%$ respectively, when $0.1 \% \mathrm{HgCl}_{2}$ was used as sterilant for 2 minutes exposure (Fig 1b), whereas it was $5.1 \%, 7.3 \%$ and $6.2 \%$ respectively for 3 minutes exposure (Table.1). There are many reports of surface sterilization of explants in plant tissue culture using $0.1 \%$ $\mathrm{HgCl}_{2}$ (Sarkar et al., 2006; Alim et al., 2014). The exposure of explants to $\mathrm{HgCl}_{2}$ may have negative effects on the survival rate of explants and $\mathrm{HgCl}_{2}$ treatments for longer period leads to browning and death of explants (Danso et al., 2011).

The sterilization treatments used in the seeds of Brinjal KKM1 variety showed better results with 91.7 per cent germination by sodium hypochlorite at $5 \%$ concentration for the duration of $3 \mathrm{~min}$ followed by mercuric chloride at $0.1 \%$ concentration for $3 \mathrm{~min}$. Also surface sterilization of explants viz., cotyledonary leaf, hypocotyl and stem showed lesser contamination percentage by using $5 \%$ sodium hypochloride for 3 minutes. Hence, this concentration of sterilant was the most effective for seeds and explants sterilization.

\section{Callus induction}

Callusing of brinjal KKM1 variety could be successfully induced using explants from in vitro germinated seedlings. The cotyledonary leaf, stem and hypocotyl were cultured on MS media with BAP, NAA, 2,4-D and IAA in 14 different combinations. Among these, MS media with hormonal combination of $2 \mathrm{mgl}^{-}$ ${ }^{1} \mathrm{NAA}$ and $0.5 \mathrm{mgl}^{-1} \mathrm{BAP}$ promoted callus induction of cotyledonary leaf explant in 6.33 days (Fig 2a) followed by MS media with 1 $\mathrm{mgl}^{-1} \mathrm{NAA}$ and $1 \mathrm{mgl}^{-1} \mathrm{BAP}$ in 6.66 days and MS media with $0.5 \mathrm{mgl}^{-1} \mathrm{IAA}$ and $2 \mathrm{mgl}^{-1} \mathrm{BAP}$ in 7.0 days.. Media with other hormonal combinations resulted in slow progress of callus induction. The maximum per cent response for callus induction is $56.66 \%$ in MS media with hormones $2 \mathrm{mgl}^{-1} \mathrm{IAA}$ and 0.5 $\mathrm{mgl}^{-1}$ BAP. MS media with $3 \mathrm{mgl}^{-1}$ 2,4-D and $1 \mathrm{mgl}^{-1}$ BAP and MS basal with $0.5 \mathrm{mgl}^{-1}$ IAA and $2 \mathrm{mgl}^{-1}$ BAP resulted in $55 \%$ callus induction using cotyledonary leaf explants (Table 2). The profuse callus proliferation was observed from cotyledon explants in MS medium containing $2 \mathrm{mgl}^{-1} \mathrm{BAP}$ or $2.5 \mathrm{mgl}^{-}$ ${ }^{1}$ BAP (Mohinder Kaur et al., 2011) and in MS with $3 \mathrm{mgl}^{-1} 2$, 4-D and $0.05 \mathrm{mgl}^{-1}$ BAP (Alim et al., 2014).

The hormonal combination of $2 \mathrm{mgl}^{-1} \mathrm{NAA}$ and $0.5 \mathrm{mgl}^{-1} \mathrm{BAP}$ in MS basal media required 9.33 days (Fig 2b) for callus induction from stem explants followed by $1 \mathrm{mgl}^{-1} \mathrm{NAA}$ and 1 
$\mathrm{mgl}^{-1}$ BAP in 9.66 days and $0.5 \mathrm{mgl}^{-1} \mathrm{IAA}$ and $2 \mathrm{mgl}^{-1} \mathrm{BAP}$ in 10.33 days. Also a significant callus induction percentage of $55 \%$ was recorded in the same hormonal combination of $2 \mathrm{mgl}^{-1} \mathrm{NAA}$ and $0.5 \mathrm{mgl}^{-1}$ BAP in MS basal media (Table 2). Ray et al., (2010) reported that the highest amount of callus was produced in MS medium containing $2.0 \mathrm{mgl}^{-1}$ BAP and $0.5 \mathrm{mgl}^{-1} \mathrm{NAA}$ using the stem explant.

The hormonal combination of $3 \mathrm{mgl}^{-1}$ 2,4-D and $0.5 \mathrm{mgl}^{-1}$ BAP used for hypocotyl explants required 12.66 days (Fig 2c) for callus induction followed by $0.5 \mathrm{mgl}^{-1} \mathrm{NAA}$ and 2 $\mathrm{mgl}^{-1} \mathrm{BAP}$ in 13 days and $3 \mathrm{mgl}^{-1} 2,4-\mathrm{D}$ in 13.33 days (Table 2). The callus induction percentage was $53.33 \%$ in the hormonal combination of $2 \mathrm{mgl}^{-1} \mathrm{NAA}$ and $0.5 \mathrm{mgl}^{-}$ ${ }^{1} \mathrm{BAP}$ and $49.66 \%$ in MS media with $2 \mathrm{mgl}^{-}$ ${ }^{1} \mathrm{BAP}$ and $0.5 \mathrm{mgl}^{-1}$ IAA. Among the three explants, cotyledonary leaf was more responsive to callus induction and proliferation compared to stem and hypocotyl explants (Fig 2d, 2e, 2f).

\section{In vitro regeneration}

Significant regeneration of shoot was achieved from cotyledonary leaf, stem and hypocotyl explants on MS media with $2 \mathrm{mgl}^{-1}$ BAP, $1 \mathrm{mgl}^{-1}$ kinetin and $0.5 \mathrm{mgl}^{-1} \mathrm{NAA}$ (Fig $2 \mathrm{~g}, 2 \mathrm{~h}, 2 \mathrm{i}$ ). Number of days taken to shoot regeneration by the explants obtained from cotyledonary leaf and stem was 38.33 and 39.33 days respectively. whereas the hypocotyl explants took 47.66 days for shoot regeneration. Number of shoots derived per callus of cotyledonary leaf is 3 per callus clump and shoot length was $3.93 \mathrm{~cm}$ in MS media with $2 \mathrm{mgl}^{-1} \mathrm{BAP}, 1 \mathrm{mgl}^{-1}$ kinetin and $0.5 \mathrm{mgl}^{-1} \mathrm{NAA}$ (Table 3; Fig 3a). Earlier reports suggest that the high frequency organogenesis of shoots was achieved from calli of cotyledonary leaf in MS supplemented with1.0 $\mathrm{mgl}^{-1} \mathrm{BAP}$ and $1.0 \mathrm{mgl}^{-1} \mathrm{Kn}$ (Sarker et al., 2006) and $2.0 \mathrm{mgl}^{-1} \mathrm{BAP}$ and $0.3 \mathrm{mgl}^{-1}$ IAA (Baradhan et al., 2012). Average number of shoots from callus of hypocotyl explants was 0.6 per callus clump when MS basal medium containing $2.5 \mathrm{mgl}^{-1} \mathrm{BAP}$ and $0.5 \mathrm{mgl}^{-1}$ IAA was used (Baradhan et al., 2012).

Half strength MS medium supplemented with $0.5 \mathrm{mgl}^{-1}$ IBA and $1.0 \mathrm{mgl}^{-1}$ IBA are more effective for root induction from the shoots derived from calli of all the three explants, cotyledonary leaf, hypocotyl and stem. The number of days taken for root formation from in vitro shoots was ranging between 26 to 29.33. The maximum number of roots recorded in $1 / 2$ MS medium supplemented with $1.0 \mathrm{mgl}^{-1}$ IBA was 2.66 to 3 per shoot and root length was $2.56 \mathrm{~cm}$ (Table 4; Fig 3b). MS basal medium was reported to be effective for root induction (Taha et al., 2002). Jadhav et al., (2014) and Zayova et al., (2012) noticed that the brinjal regenerated shoots successfully formed roots on MS hormone-free medium and also in medium containing $0.1 \mathrm{mgl}^{-1}$ IBA when in vitro shoots from calli of the explants, cotyledon and hypocotyl were used for root formation.

The plantlets after sufficient development of root system, were taken carefully from the culture tubes and the agar was washed in running tap water. The plantlets were transferred to small plastic pots containing sterilized sand, soil and FYM in 1:2:1 ratio and kept inside the polyhouse for two to three weeks for acclimatization (Fig 3c). After three weeks the plants were transferred to small earthern pot and kept inside the glasshouse (Fig 3d).

In conclusion the brinjal var.KKM1, is highly susceptible to Phytoplasma infection and hence to eliminate it by tissue culture techniques, standardization of a protocol for regeneration is attempted. 
Table.1 Effect of different chemicals on in vitro germination of brinjal var. KKM1 seeds and sterilization of explants

\begin{tabular}{|c|c|c|c|c|c|c|c|c|c|}
\hline \multirow[t]{2}{*}{ S.No } & \multirow[t]{2}{*}{ Treatment } & \multirow[t]{2}{*}{ Sterilant } & \multirow[t]{2}{*}{ Concentration (\%) } & \multirow[t]{2}{*}{ Duration } & \multicolumn{2}{|l|}{ Seeds } & Cotyledonary leaf & Stem & Hypocotyl \\
\hline & & & & & Germination \%* & Contamination $\% *$ & \multicolumn{3}{|c|}{ Contamination $\% *$} \\
\hline 1 & $\mathrm{~T} 1$ & $\mathrm{NaOCl}$ & 5 & $3 \mathrm{~min}$ & 91.70 & 5.10 & 3.86 & 5.20 & 6.00 \\
\hline 2 & $\mathrm{~T} 2$ & $\mathrm{NaOCl}$ & 5 & $5 \mathrm{~min}$ & 50.40 & 6.73 & 6.23 & 8.30 & 7.30 \\
\hline 3 & T3 & $\mathrm{HgCl}_{2}$ & 0.1 & $2 \min$ & 41.70 & 6.06 & 8.86 & 8.40 & 8.40 \\
\hline 4 & $\mathrm{~T} 4$ & $\mathrm{HgCl}_{2}$ & 0.1 & $3 \mathrm{~min}$ & 73.33 & 7.10 & 5.10 & 7.30 & 6.20 \\
\hline 5 & T5 & Ethanol & 70 & $10 \mathrm{sec}$ & 8.16 & 8.40 & 22.3 & 26.53 & 36.00 \\
\hline 6 & T6 & Ethanol & 70 & $30 \mathrm{sec}$ & 16.23 & 15.33 & 25.7 & 29.36 & 38.50 \\
\hline \multicolumn{5}{|c|}{ CD value (0.0.5) } & 1.137 & 0.139 & 0.178 & 0.840 & 1.036 \\
\hline
\end{tabular}

* Mean of three replications

The treatment means are compared using Duncan Multiple Range Test (DMRT).

The mean followed by common letter(s) are not significantly different $(\mathrm{p}=0.05)$.

Table.2 Effect of different hormonal combinations on callus induction from cotyledonary leaf, stem and hypocotyls of brinjal variety KKM1

\begin{tabular}{|c|c|c|c|c|c|c|c|c|c|}
\hline \multicolumn{4}{|c|}{ Hormonal combination $\mathrm{mgl}^{-1}$} & \multicolumn{2}{|c|}{ Cotyledonary leaf } & \multicolumn{2}{|l|}{ Stem } & \multicolumn{2}{|l|}{ Hypocotyl } \\
\hline 2,4 D & BAP & IAA & NAA & Days to callus induction * & callus induction $\% *$ & $\begin{array}{l}\text { Days to callus } \\
\text { induction * }\end{array}$ & $\begin{array}{c}\text { callus induction } \\
\%_{*} *\end{array}$ & $\begin{array}{l}\text { Days to callus } \\
\text { induction * }\end{array}$ & $\begin{array}{c}\text { callus induction } \\
\% *\end{array}$ \\
\hline 2 & - & - & - & $12.00^{\mathrm{bcd}}$ & $25.00^{\mathrm{e}}$ & $13.66^{\mathrm{bcd}}$ & $25.00^{\text {def }}$ & $15.66^{\text {bcde }}$ & $18.33^{\mathrm{d}}$ \\
\hline 3 & - & - & - & $13.00^{\mathrm{abc}}$ & $29.33^{\text {cde }}$ & $13.00^{\mathrm{cd}}$ & $28.33^{\mathrm{cd}}$ & $13.33^{\mathrm{fgh}}$ & $45.00^{\mathrm{a}}$ \\
\hline 2 & 0.5 & - & - & $12.66^{\mathrm{bc}}$ & $28.33^{\mathrm{de}}$ & $12.00^{\mathrm{de}}$ & $33.33^{\mathrm{bc}}$ & $16.66^{\mathrm{abc}}$ & $30.00^{\mathrm{bc}}$ \\
\hline 2 & 1 & - & - & $14.33^{\mathrm{a}}$ & $35.00^{\text {bcd }}$ & $15.00^{\mathrm{ab}}$ & $35.00^{b}$ & $18.00^{\mathrm{a}}$ & $23.33^{\mathrm{bcd}}$ \\
\hline 3 & 0.5 & - & - & $12.33^{\mathrm{bcd}}$ & $35.00^{\mathrm{bcd}}$ & $14.00^{\mathrm{bc}}$ & $21.66^{\mathrm{ef}}$ & $12.66^{\mathrm{h}}$ & $46.66^{\mathrm{a}}$ \\
\hline 3 & 1 & - & - & $9.33^{\mathrm{e}}$ & $55.00^{\mathrm{a}}$ & $14.33^{\mathrm{abc}}$ & $20.00^{f}$ & $14.33^{\mathrm{efg}}$ & $26.66^{\mathrm{bcd}}$ \\
\hline- & 2 & 0.5 & - & $7.00^{f}$ & $55.00^{\mathrm{a}}$ & $10.33^{\mathrm{ef}}$ & $55.00^{\mathrm{a}}$ & $13.33^{\text {fgh }}$ & $49.66^{\mathrm{a}}$ \\
\hline - & 1 & 1 & - & $9.00^{\mathrm{e}}$ & $53.33^{\mathrm{a}}$ & $13.00^{\mathrm{cd}}$ & $26.66^{\text {de }}$ & $15.00^{\mathrm{de}}$ & $25.00^{\mathrm{bcd}}$ \\
\hline - & 1.5 & 1.5 & - & $11.00^{\mathrm{d}}$ & $40.00^{b}$ & $15.33^{\mathrm{ab}}$ & $21.66^{\mathrm{ef}}$ & $16.00^{\mathrm{bcd}}$ & $20.00^{\mathrm{cd}}$ \\
\hline - & 0.5 & 2 & - & $9.00^{\mathrm{e}}$ & $56.66^{\mathrm{a}}$ & $13.66^{\mathrm{bcd}}$ & $26.66^{\mathrm{de}}$ & $17.00^{\mathrm{ab}}$ & $33.33^{\mathrm{b}}$ \\
\hline - & 2 & - & 0.5 & $11.66^{\mathrm{cd}}$ & $36.66^{\mathrm{bc}}$ & $16.00^{\mathrm{a}}$ & $20.00^{f}$ & $13.00^{\mathrm{gh}}$ & $45.00^{\mathrm{a}}$ \\
\hline - & 1 & - & 1 & $6.66^{\mathrm{f}}$ & $53.33^{\mathrm{a}}$ & $9.66^{\mathrm{f}}$ & $55.00^{\mathrm{a}}$ & $16.00^{\mathrm{bcd}}$ & $26.66^{\mathrm{bcd}}$ \\
\hline - & 1.5 & - & 1.5 & $13.33^{\mathrm{ab}}$ & $36.66^{\mathrm{bc}}$ & $14.33^{\mathrm{abc}}$ & $21.66^{\mathrm{ef}}$ & $15.33^{\text {cde }}$ & $20.00^{\mathrm{cd}}$ \\
\hline - & 0.5 & - & 2 & $6.33^{\mathrm{f}}$ & $53.33^{\mathrm{a}}$ & $9.33^{\mathrm{f}}$ & $55.00^{\mathrm{a}}$ & $14.66^{\text {def }}$ & $53.33^{\mathrm{a}}$ \\
\hline \multicolumn{4}{|c|}{ CD value (0.05) } & 1.652 & 7.864 & 1.712 & 6.451 & 1.526 & 10.079 \\
\hline
\end{tabular}

*Mean of three replications

The treatment means are compared using Duncan Multiple Range Test (DMRT).

The mean followed by common letter(s) are not significantly different $(\mathrm{p}=0.05)$ 
Table.3 Effect of different hormonal combinations on in vitro shoot regeneration of the calli derived from cotyledonary leaf,stem and hypocotyls of brinjal variety KKM1

\begin{tabular}{|c|c|c|c|c|c|c|}
\hline \multirow[t]{2}{*}{ Calli } & \multicolumn{3}{|c|}{$\begin{array}{c}\text { Harmonal combinations } \\
(\mathbf{m g} / \mathbf{l})\end{array}$} & \multirow[t]{2}{*}{$\begin{array}{l}\text { Days required for shoot } \\
\text { regeneration* }\end{array}$} & \multirow[t]{2}{*}{$\begin{array}{l}\text { Number of shoots } \\
\text { per explants* }\end{array}$} & \multirow[t]{2}{*}{$\begin{array}{c}\text { Shoot } \\
\text { length }(\mathbf{c m})^{*}\end{array}$} \\
\hline & BAP & NAA & kinetin & & & \\
\hline \multirow{4}{*}{$\begin{array}{l}\text { Calli } \quad \text { from } \\
\text { cotyledonary leaf }\end{array}$} & 3 & - & - & $42.33^{\mathrm{d}}$ & $1.00^{\mathrm{d}}$ & $3.06^{\mathrm{e}}$ \\
\hline & 3 & 0.5 & - & $45.33^{c}$ & $1.33^{\mathrm{cd}}$ & $3.26^{\mathrm{cd}}$ \\
\hline & 2 & - & 1 & $42.66^{\mathrm{d}}$ & $1.33^{\mathrm{cd}}$ & $3.26^{\mathrm{cd}}$ \\
\hline & 2 & 0.5 & 1 & $38.33^{\mathrm{e}}$ & $3.00^{\mathrm{a}}$ & $3.93^{\mathrm{a}}$ \\
\hline \multirow[t]{4}{*}{ Calli from stem } & 3 & - & - & $45.66^{\mathrm{c}}$ & $1.66^{\mathrm{cd}}$ & $3.10^{\mathrm{e}}$ \\
\hline & 3 & 0.5 & - & $47.00^{\mathrm{b}}$ & $1.66^{\mathrm{cd}}$ & $3.33^{\mathrm{c}}$ \\
\hline & 2 & - & 1 & $47.33^{\mathrm{ab}}$ & $1.00^{\mathrm{d}}$ & $3.13^{\mathrm{de}}$ \\
\hline & 2 & 0.5 & 1 & $39.33^{\mathrm{e}}$ & $2.66^{\mathrm{ab}}$ & $4.03^{\mathrm{a}}$ \\
\hline \multirow{4}{*}{$\begin{array}{ll}\text { Calli } & \text { from } \\
\text { hypocotyl } & \end{array}$} & 3 & - & - & $48.33^{\mathrm{a}}$ & $1.66^{\mathrm{cd}}$ & $3.56^{\mathrm{b}}$ \\
\hline & 3 & 0.5 & - & $48.33^{\mathrm{a}}$ & $1.33^{\mathrm{cd}}$ & $3.00^{\mathrm{e}}$ \\
\hline & 2 & - & 1 & $48.33^{\mathrm{a}}$ & $1.66^{\mathrm{cd}}$ & $3.30^{\mathrm{c}}$ \\
\hline & 2 & 0.5 & 1 & $47.66^{\mathrm{ab}}$ & $2.00^{\mathrm{bc}}$ & $4.00^{\mathrm{a}}$ \\
\hline \multicolumn{4}{|c|}{ CD value $(0.05)$} & 1.051 & 0.932 & 0.159 \\
\hline
\end{tabular}

*Mean of three replications

The treatment means are compared using Duncan Multiple Range Test (DMRT).

The mean value followed by common letter(s) are not significantly different $(\mathrm{p}=0.05)$.

Table.4 Effect of different hormonal combinations on in vitro root formation from the shoots derived from calli of cotyledonary leaf, stem and hypocotyls of brinjal variety KKM1

\begin{tabular}{|l|l|c|c|c|}
\hline Shoot & $\begin{array}{l}\text { Hormonal } \\
\text { combinations }\end{array}$ & $\begin{array}{c}\text { Days required for } \\
\text { root } \\
\text { regeneration* }\end{array}$ & $\begin{array}{c}\text { Number of } \\
\text { roots per } \\
\text { plant* }^{*}\end{array}$ & Root length(cm)* $^{*}$ \\
\hline $\begin{array}{l}\text { Shoots derived from } \\
\text { calli of cotyledonary } \\
\text { leaf explants }\end{array}$ & IBA $0.5 \mathrm{mg} / \mathrm{l}$ & $26.00^{\mathrm{b}}$ & $1.33^{\mathrm{b}}$ & $2.26^{\mathrm{b}}$ \\
\hline $\begin{array}{l}\text { Shoots derived from } \\
\text { calli of stem explants }\end{array}$ & IBA $1.0 \mathrm{mg} / \mathrm{l}$ & $27.66^{\mathrm{ab}}$ & $3.00^{\mathrm{a}}$ & $2.16^{\mathrm{bc}}$ \\
\hline & IBA $1.0 .5 \mathrm{mg} / \mathrm{mg} / \mathrm{l}$ & $28.33^{\mathrm{a}}$ & $1.33^{\mathrm{b}}$ & $2.13^{\mathrm{c}}$ \\
\hline $\begin{array}{l}\text { Shoots derived } \\
\text { fromcalli of } \\
\text { hypocotyl explants }\end{array}$ & IBA $0.5 \mathrm{mg} / \mathrm{l}$ & $29.33^{\mathrm{a}}$ & $2.66^{\mathrm{a}}$ & $2.56^{\mathrm{a}}$ \\
\hline & IBA $1.0 \mathrm{mg} / \mathrm{l}$ & $27.33^{\mathrm{ab}}$ & $1.33^{\mathrm{b}}$ & $2.20^{\mathrm{bc}}$ \\
\hline CD value (0.05) & & $28.66^{\mathrm{a}}$ & $2.66^{\mathrm{a}}$ & $2.53^{\mathrm{a}}$ \\
\hline
\end{tabular}

*Mean of three replications

The treatment means are compared using Duncan Multiple Range Test (DMRT).

The mean followed by common letter(s) are not significantly different $(\mathrm{p}=0.05)$. 
Fig.1 In vitro seed germination of brinjal variety KKM1 seeds using different sterilants

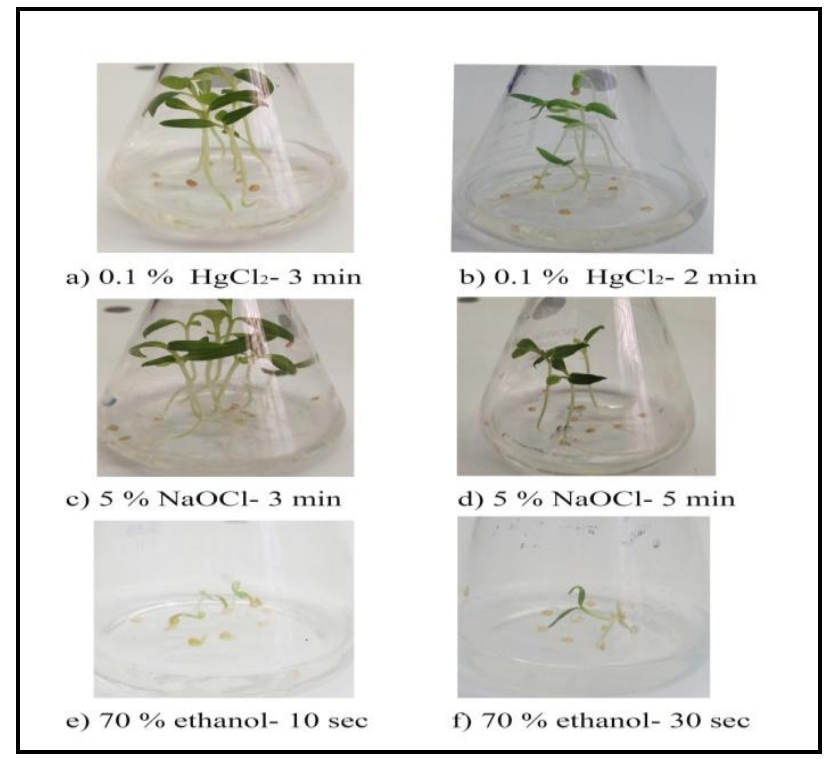

Fig.2 Callus induction and regeneration of cotyledonary leaf, stem and hypocotyls explants

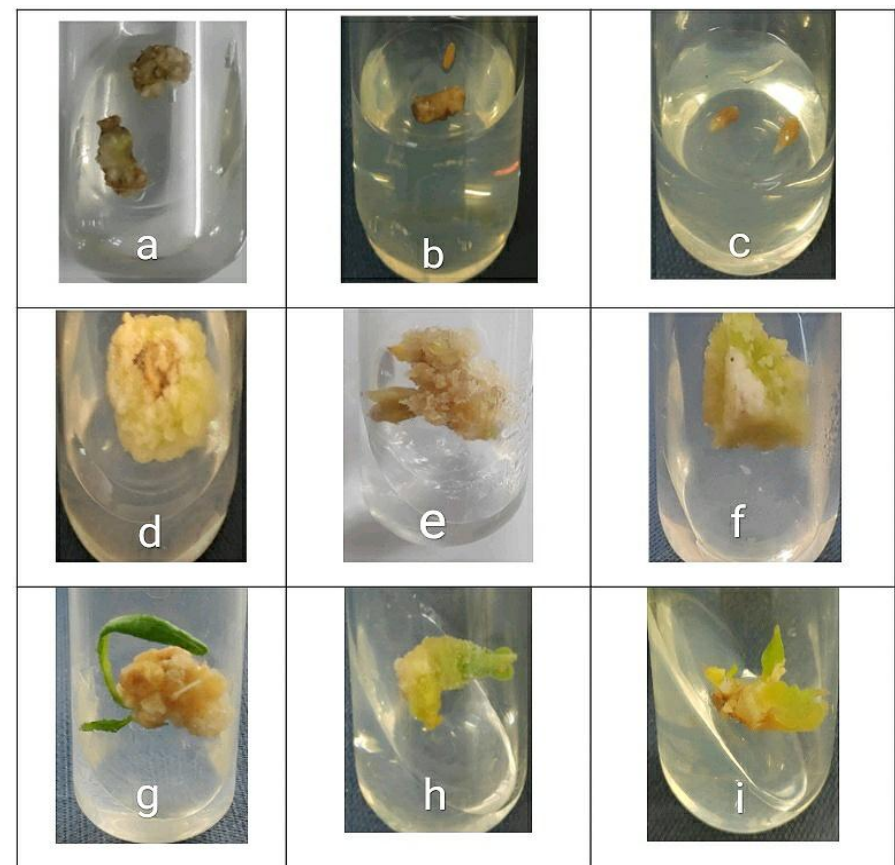

a. Callus induction of cotyledonary leaf explant in 6.33 days using MS $+2 \mathrm{mg} / \mathrm{l} \mathrm{NAA}$ and $0.5 \mathrm{mg} / \mathrm{l} \mathrm{BAP}$; b. Callus induction of stem explant in 9.33 days using MS $+2 \mathrm{mg} / \mathrm{l} \mathrm{NAA}$ and $0.5 \mathrm{mg} / \mathrm{l} \mathrm{BAP}$; c. Callus induction of hypocotyl explants in 12.66 days using MS $+3 \mathrm{mg} / 1$ 2,4-D and $0.5 \mathrm{mg} / 1 \mathrm{BAP}$; $\mathrm{d}$. Callus proliferation from cotyledonary leaf explants after 20 days (MS $+2 \mathrm{mg} / \mathrm{l} \mathrm{NAA}$ and $0.5 \mathrm{mg} / \mathrm{l} \mathrm{BAP}$ ) ; e. Callus proliferation from stem explants after 20 days (MS + $2 \mathrm{mg} / \mathrm{l} \mathrm{NAA}$ and $0.5 \mathrm{mg} / \mathrm{l} \mathrm{BAP}$ ) ; f. Callus proliferation from hypocotyls explants after 20 days (MS + $3 \mathrm{mg} / 1$ 2,4-D and $0.5 \mathrm{mg} / \mathrm{l} \mathrm{BAP}$ ); g. shoot regeneration from cotyledonary leaf explants after 38.33 days using MS + $2 \mathrm{mg} / \mathrm{l} \mathrm{BAP}, 1 \mathrm{mg} / \mathrm{l} \mathrm{kinetin}$ and $0.5 \mathrm{mg} / \mathrm{l} \mathrm{NAA}$; h. shoot regeneration from stem explants after 39.33 days using MS $+2 \mathrm{mg} / \mathrm{l} \mathrm{BAP}, 1 \mathrm{mg} / \mathrm{l}$ kinetin and $0.5 \mathrm{mg} / \mathrm{l} \mathrm{NAA}$; i. shoot regeneration from hypocotyls explants after 47.66 days using MS + $2 \mathrm{mg} / \mathrm{l} \mathrm{BAP,} 1 \mathrm{mg} / \mathrm{l} \mathrm{kinetin}$ and $0.5 \mathrm{mg} / \mathrm{l} \mathrm{NAA}$ 
Fig.3 In vitro formation of shoots and roots and hardening of brinjal var.KKM1 from cotyledonary leaf explants

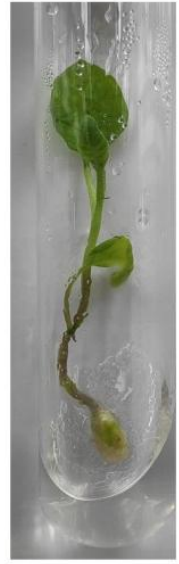

a)

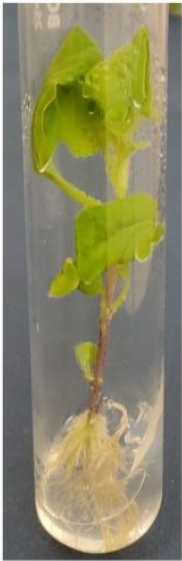

b)

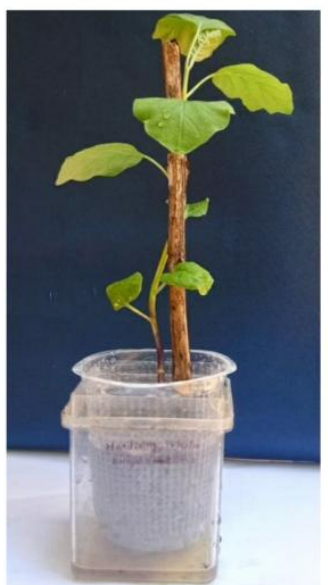

c)

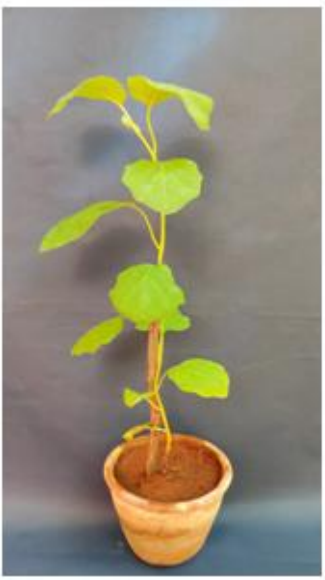

d)

Shooting of callus from cotyledonary leaf explants using MS $+2 \mathrm{mg} / \mathrm{l} \mathrm{BAP}, 1 \mathrm{mg} / \mathrm{l}$ kinetin and $0.5 \mathrm{mg} / \mathrm{l} \mathrm{NAA}$, b. Rooting of shoots derived from the callus of cotyledonary leaf explants using $1 / 2 \mathrm{MS}+1.0 \mathrm{mg} / \mathrm{lBA}$, c. Hardening of in vitro developed plantles of brinjal variety KKM1, d. In vitro regenerated plants transferred to pot.

Surface sterilization with sodium hypochlorite at $5 \%$ concentration for $3 \mathrm{~min}$ exposure is efficient in eliminating contamination in all the three explants taken from in vitro germinated seedlings. The callus induction and proliferation was prominent on MS medium containing $2.0 \mathrm{mgl}^{-1} \mathrm{NAA}$ and 0.5 $\mathrm{mgl}^{-1}$ BAP from cotyledonary leaf. The shoot regeneration through callus from cotyledonary leaf and stem was efficient in MS media with $2 \mathrm{mgl}^{-1} \mathrm{BAP}, 1 \mathrm{mgl}^{-1}$ kinetin and $0.5 \mathrm{mgl}^{-1}$ NAA. Half strength MS medium supplemented with 0.5 and $1.0 \mathrm{mgl}^{-1}$ IBA was more effective for root induction. To conclude, this sterilization protocol for explants of brinjal var.KKM1 and regeneration protocol will be highly useful to produce in vitro brinjal plants for resistance to little leaf of brinjal caused by Phytoplasma.

\section{References}

Alim et al., (2014). Callus induction of brinjal by genotype and growth regulators. J. Expt. Biosci. 5(2):35-42.

Anoop Badoni and Chauhan, J.S. 2010. In
Vitro Sterilization Protocol for Micropropagation of Solanum tuberosum cv. 'Kufri Himalini'. Academia Arena. 2(4).

Bardhan, S.K., Sharma, S., and Srivastava, D.K. 2012. In vitro plant regeneration studies in brinjal. Journal of Cell and Tissue Research .12 (2):3213.

CPRI (Central Potato Research Institute) 1992. Tissue Culture Technique for Potato Health, Conservation, Micropropagation and Improvement. CPRI, Shimla, 23 p.

Danso et al (2011). Effective decontamination and subsequent plantlet regeneration of sugarcane (Sacchrum officinarum L.) in vitro. Int. J. Integra. Biol . 11:90-96.

Dodds et al., (1985). Experiments in plant tissue culture. International Potato Center.

Durosomo, H.A., Popoola, A.R., Afolabi, C.G., and Idehen, G.O. 2014. Germination and In vitro regeneration response of local Nigerian tomato cultivar using different explant source. Nigerian Journal of Biotechnology. 28 
(1):35-42.

Jadhav, M.A., Jadhav, A.S., Pawar, B.D., Kale, A.A., and Kute, N.S. 2014. Influence of genotype, explant and growth regulators on in vitro regeneration of brinjal (Solanum melongena L.). Journal of cell and tissue research vol. 14(2) 4595-4600.

Kaur et al (2011). In vitro plant regeneration in brinjal from cultured seedling explants. Indian Journal of Horticulture. 68 (1):61-65.

Khan and Reayat. 1979. Solanum melongena and its ancestral forms. Linnean Society symposium series.

Magioli, Claudia, and Elisabeth Mansur. 2005. Eggplant (Solanum melongena L.): tissue culture, genetic transformation and use as an alternative model plant. Acta Botanica Brasilica. 19 (1):139-148.

Maina, Susan Muthoni, Quinata Emongor, Kiran K Sharma, Simon T Gichuki, Moses Gathaara, and Santie M de Villiers. 2010. Surface sterilant effect on the regeneration efficiency from cotyledon explants of groundnut (Arachis hypogea L.) varieties adapted to eastern and Southern Africa. African Journal of Biotechnology. 9 (20).

Mitra, D.K. 1993. Little leaf, a serious disease of eggplant (Solanum melongena) Management of Plant Diseases Caused by Fastidious Prokaryotes. Eds
Raychaudhuri SP, Teakle DS. Associated Publishing Co, New Delhi, India:73-78.

Rao et al (2011). Phytoplasma diseases affecting various plant species in India. Acta Phytopathologica et Entomologica Hungarica. 46 (1):59-99. Ray, B.P., Hassan, L., and Sarker, S.K. 2010. Plant Regeneration from Seedling Derived Explants through Callus of Eggplant (Solanum melongena L). The Agriculturists. 8(2): 98-107.

Sarker, R.H., Sabina Yesmin, and Hoque, M.I. 2006. Multiple shoot formation in eggplant (Solanum melongena L.). Plant Tissue Culture and Biotechnology. 16 (1):53-61.

Sen et al (2013). In vitro sterilization protocol for micropropagation of Achyranthes aspera L. node. International Research Journal of Biotechnology. 4 (5):89-93.

Taha, R.M., and Tijan, M. 2002. An in vitro production and field transfer protocol for Solanum melongena plants. South African J. Bot. 68: 447-450.

Thomas, K.M., Krishnaswami, C.S., 1939. Little leaf, a transmissible disease of brinjal. Proc. Ind. Nat. Sci. Acad. 10:201-212.

Zayova, E., Vassilevska-Ivanova, R., Kraptchev, B. and Stoeva, D. 2012. Indirect shoot organogenesis of eggplant (Solanum melongena L.). J. Cent. Eur .Agr. 13(3): 446-457.

\section{How to cite this article:}

Nivetha, A., S. Merina Prem Kumari, R. Kannan, R. Arulmozhiyan, N. Rajinimala and Arumugam Pillai, M. 2020. Indirect Organogenesis for Regeneration in Brinjal (Solanum melongena L.) Var. KKM 1. Int.J.Curr.Microbiol.App.Sci. 9(07): 2517-2526. doi: https://doi.org/10.20546/ijcmas.2020.907.295 